\title{
PENGAWASAN KREDIT PT. BANK PERKREDITAN RAKYAT (BPR) OPHIR PASAMAN BARAT
}

\author{
Beti Andriani, Romi Susanto \\ Akademi Keuangan dan Perbankan Padang \\ romisusanto@akbpstie.ac.id
}

\begin{abstract}
The purpose of this study was to determine the credit supervision at. Rural Banks (BPR) West Pasaman Ophir and should be done PT. BPR Ophir West Pasaman in minimizing the credit crunch. The focus of this research is focused on: Credit Monitoring conducted by PT. Rural Banks (BPR) Ophir Pasaman Barat. The research result is a credit monitoring result showed that the surveillance of credit at PT. Rural Banks (BPR) Ophir Pasaman can be seen in several process stages of the loan application, the assessment of the validity of data or files, 5C analysis, provision of credit terms, and conditions of the guarantee have started well, but there are shortcomings in the supervision of another, at the proposal stage credit there are still weaknesses in the determination of a credit limit that is lack of time and lack of credit staff personnel. Efforts made by PT. Rural Bank to overcome these obstacles is to perform a careful analysis of the character of prospective borrowers, the ability of prospective borrowers, owned capital, business conditions and guarantees provided by the debtor.

It is suggested in order to bank lending is more selective and careful in terms of analyzing the ability of the debtor to pay off his credit and prioritize the precautionary principle in order to avoid mistakes that will cause bad credit.
\end{abstract}

Keywords : Supervision of credit

\section{PENDAHULUAN}

Dalam persaingan dunia bisnis terutama dalam keuangan perlu adanya pengawasan gunanya untuk mempermudah terjadinya transaksi dalam pemberian kredit, yang akan berimplikasi terhadap berbagai aspek seperti, terhadap lembaga keuangan yang terlibat, aspek hukum pihak-pihak yang terkait, mekanisme penyelesaian risiko, yang kesemuanya itu dapat memberikan dampak kepada sistem lembaga keuangan dan perekonomian.

Pada dasarnya pengembangan perekonomian masyarakat, ditujukan pada dua sasaran pokok yaitu meningkatkan kemampuan produksi, serta terciptanya lapangan kerja baru bagi angkatan kerja yang setiap tahunnya meningkat, namun dikarenakan adanya keterbatasan modal produksi dalam usaha meningkatkan perekonomian tersebut, bantuan dari bank dalam bentuk tambahan modal atau yang disebut dengan kredit sangat dibutuhkan. Hal ini disebabkan karena kebutuhan masyarakat manusia yang beraneka ragam selalu meningkat, sementara kemampuan untuk mencapai sesuatu yang diinginkan terbatas sehingga terjadilah kesenjangan antara kemampuan dan cita-cita. 
Bank merupakan salah satu lembaga keuangan yang mempunyai peranan yang sangat penting bagi aktivitas perekonomian. Dalam upaya mencapai tujuan pembangunan yang dilakukan, baik

kebijakan fiskal maupun kebijakan moneter yang dilakukan oleh pemerintah yaitu di bidang perbankan. Salah satu produk dari PT. bank perkreditan rakyat (BPR) ophir adalah kredit, di mana hingga saat ini masih merupakan aktiva produktif yang memberikan pendapatan utama kegagalan suatu bank karena mengandung risiko tinggi yang dapat mempengaruhi tingkat kesehatan dan kelangsungan hidup suatu bank. Maka hal ini yang dirasa penting untuk dikaji dan diteliti dalam pengelolaan lembaga keuangan yang bergerak dalam usaha perkreditan adalah Pengawasan kredi pada PT. Bank Perkreditan Rakyat (BPR) Ophir. Standar pengawasan kredit bertujuan yaitu agar berkurangnya masalah kredit macet, serta memberi pedoman yang jelas atas syarat-syarat pengajauan kredit yang harus dipenuhi oleh calon nasabah.

Oleh karena itu manajemen kredit sangat penting dilakukan dalam penyaluran dana agar bank tidak mengalami kredit macet karena pada kenyataanya kredit yang diberikan kepada nasabah hanya mengalami kendala, yaitu melaksanakan fungsi pengawasan dengan baik.

Adapun faktor-faktor penyebab terjadinya kredit bermasalah antara lain, kurangnya pengawasan pada calon nasabah, kurangnya analisa kredit, dan tidak adanya itikad baik dari nasabah.

Untuk kelangsungan usaha bank sangat ditentukan oleh kesiapan bank untuk mengahadapi risiko kerugian dari kredit yang disalurkan. Oleh karena itu bank perlu melakukan pengawasan lebih awal terhadap nasabah yang akan mendapatkan fasilitas kredit untuk kelancaran pelaksanaan perkreditan melalui bank, satu hal yang sangat penting adalah masalah pengawasan yang terus-menerus sebagai usaha mencegah timbulnya kredit macet karena fungsi pengawasan bersifat mencegah, maka pengawasan disebut sebagai antisipasi terhadap timbulnya kredit macet yang ada pada bank. Melalui pengawasan yang intensif diharapkan semua kredit yang disalurkan oleh bank dapat kembali sesuai dengan jangka waktu yang telah ditentukan.

Pengawasan kredit merupakan upaya yang ditempuh suatu lembaga bank, dalam usahanya untuk menghindari kemungkinan terjadinya kredit macet atau tunggakkan bagi kredit yang telah sampai jatuh temponya. Pada hakekatnya pengawasan kredit macet adalah suatau tindakan yang digunakan untuk menghindari terjadinya kemacetan kredit yang berkelanjutan. Sehingga pengawasan kredit macet berguna untuk mencegah terjadinya kredit macet.

Melihat pentingnya pengawasan kredit dan supaya nasabah konsisten terhadap perjanjian yang telah disepakati sebelumnya, maka penulis sangat tertarik untuk melakukan penelitian dengan judul "Pengawasan Kredit Pada PT. Bank Perkreditan Rakyat (BPR) Ophir Pasaman Barat”.

\section{Rumusan Masalah}

Berdasarkan berdasarkan uraian latar belakang tersebut, maka yang di bahas dalam tugas akhir ini yaitu : Bagaimana pengawasan kredit yang dilakukan oleh PT. Bank Perkreditan Rakyat (BPR) Ophir Pasaman Barat?

\section{Tujuan Penelitian}

Berdasarkan dari rumusan masalah yang telah diuraikan di atas, maka penelitian ini bertujuan untuk mengetahui perlunya pengawasan kredit dan mengetahui prosedur pemberian kredit pada PT. BPR Ophir Pasaman Barat. 


\section{Manfaat Penelitian}

Adapun manfaat yang diperoleh dari penulis maupun pihak Bank tempat melakukan penelitian ini adalah sebagai berikut :

a. Bagi Penulis

Penulisan tugas akhir ini berguna untuk memenuhi persyaratan Akademik dalam menyelesaikan program studi Diploma III Keungan Dan Perbankan Pembangunan (KBP) Padang, dan sebagai bahan perbandingan antara teori yang diperoleh selama perkuliahan serta untuk menerapkan ilmu dan yang telah penulis jumpai selama dibangku perkuliahan. b. Bagi PT. Bank Perkreditan Rakyat Pasaman Barat.

Berguna sebagai bahan masukan bagi PT. Bank Perkreditan Rakyat Ophir Pasaman Barat dan dapat menjadi bahan pertimbangan dalam pemberian kredit dan pengawasan kredit dimasa yang akan datang.

c. Bagi Pihak lain

Diharapkan hasil penelitian ini dapat menambah referensi, informasi dan wawasan untuk penelitian lebih lanjut atau sebagai bahan kepustakaan serta sumber pengetahuan.

\section{METODE PENELITIAN}

Teknik pengumpulan data riset lapangan yaitu peninjauan langsung ke objek penelitian yang dipilih untuk meneliti hasil data skunder. Penelitian langsung kelapangan ini akan dapat membantu penulisan untuk melengkapi data yang diperlukan. Adapun cara riset lapangan ini adalah dengan mewawancarai langsung ke pihak-pihak yang berkepentingan dalam hal ini adalah PT. BPR OPHIR atau instansi yang terkait.

Riset perpustakaan Yaitu penyelidikan yang dilakukan melalui kepustakaan ataupun bukubuku ilmiah dan tulisan-tulisan yang ada hubunganya dengan pembahasan yang dilalukan. Penelitian perpustakaan ini bersifat teoritis, dimana dapat diaplikasikan dengan teori-reori yang berhubunga dengan penulisan ini.

Sedangkan teknik analisa datanya yaitu untuk menganalisa data penelitian, penulis menggunakan analisa kualitatif. Dengan metode ini penulis akan mencoba memberikan fakta-fakta atau kenyataan yang dialami dengan teori-teori yang ada.

\section{LANDASAN TEORI}

\section{Pengertian Bank Perkreditan Rakyat}

Bank perkreditan rakyat (BPR) adalah lembaga keuangan bank yank menerima simpanan hanya dalam bentuk deposito berjangka, tabungan, dan atau bentuk lainnya yang dipersamakan dan menyalurkan dana sebagai usaha BPR.

Dengan lokasi yang pada umumnya dengan dengan tempat masyarakat yang membutuhkan. Status BPR diberikan kepada bank desa, bank pasar, bank pegawai, lumbung pitih nagari (LPN), lembaga perkreditandesa (LPD), badan kredit desa (BKD), badan kredit kecamatan (BKK), dan lain - lain, yang dipersamakan berdasarkan UU Perbankan Nomor 7 Tahun 1992 dengan memenuhi persyaratan tatacara yang ditetapkan dengan peraturan pemerintah.

Ketentuan tersebut diberlakukan karena memingingat bahwa lembaga-lembaga telah berkembang dari lingkungan masyarakat indonesia, serta masih diperlukan oleh masyarakat, oleh karena itu, UU Perbankan Nomor 7 Tahun 1992 memberikan kejelasan status lembaga-lembaga dimaksud untuk menjamin kesatuan dan keseragaman dalam pembinaan dan pengawasan, maka persyaratan dan tatacara pemberian status lembaglembaga dimaksud ditetapkan dengan peraturan pemerintah.

Menurut Undang-Undang RI Nomor 10 tahun 1998 atas perubahan UU 7 Tahun 1992 pasal 1 ayat (2) tentang perbankan, yang dimaksud dengan bank adalah badan usaha 
yang menghimpun dana dari masyarakat dalam bentuk simpanan dan menyalurkannya kepada masyarakat dalam kredit dan bentuk-bentuk lainnya dalam rangka meningkatkan taraf hidup orang banyak.

\section{Pengertian Kredit}

Kredit adalah kemampuan untuk melaksanakan suatu pembelian atau mengadakan suatu pinjaman dengan suatu janji, pembayaran akan dilaksanakan pada jangka waktu yang telah disepakati “. (Astiko, Manajemen Perkreditan ( Yogyakarta : andi Offset, 1996 ), hal 5).

Sedangkan pengertian kredit menurut Undang-Undang Perbankan Nomor 10 Tahun 1998:

Kredit adalah penyediaan uang atau tagihan yang dapat disamakan dengan itu, berdasarkan persetujuan atau kesepakatan pinjam-meminjam antara bank dengan pihak lain yang mewajibkan pihak peminjam untuk melunasi utangnya setelah jangka waktu tertentu dengan pemberian bunga.

\section{Pengertian Pengawasan Kredit}

Pengawasan merupakan salah satu fungsi manajemen. Pengawasan redit itu merupakan suatu proses internal control mulai dari saat permohonan sampai dengan kredit itu dilunasi. Pengawasan kredit diartikan salah satu fungsi manajemen yang berupaya untuk menjaga dan mengamankan kredit itu sebagai kekayaan bank dan dapat mengetahui asumsi-asumsi dasar persetujuan, kredit itu akan tercapai atau malah terjadi penyimpangan.

Dengan demikian pengawasan kredit merupakan langkah pengawasan terhadap fasilitas kredit yang diberikan secara keseluruhan maupun secara individual kepada debitur dimana apakah pelaksanaan pengawasan kredit sesuai dengan rencana yang disusun atau tidak.

\section{Fungsi Dan Tujuan Pengawasan Kredit}

Fungsi Pengawasan Kredit (FPK) adalah fungsi yang melakukan perencanaan, persiapan, pelaksanaan, dan pengendalian dalam kegiatan pemutusan sementara, penyambungan kembali, pemutusan rampung bagi pelanggan yang terlambat membayar piutang pelanggan dan menyelesaikan penghapusan piutang ragu-ragu.

Sedangkan tujuan pengawasan kredit kredit merupakan faktor dominan dalam aset bank, bahkan merupakan sumber utama pendapatan bagi sebuah bank komersil. Oleh karena itu, seharusnya setiap tahap dalam pemberian kredit mendapat perhatian agar tujuan dan sasaran kredit dapat dicapai. Tujuan dan sasaran kredit dapat dicapai bila dapat diupayakan tercipta kredit yang sehat. Dalam pengertian pengawasan kredit yang diuraikan di atas secara jelas tujuannya adalah sebagai penjaga dan pengaman dalam pengelolaan tahap-tahap pemberian kredit. Secara rinci tujuan pengawasan dapat dijelaskan sebagai berikut :

a. Agar penjagaan dan pengawasan dalam pengelolaan kekayaan bank di bidang perkreditan dapat dilakukan dengan baik, untuk menghindarkan penyelewengan baik dari intern maupun ekstern bank.

b. Untuk memastikan ketelitian dan kebenaran data administrasi di bidang perkreditanserta penyusunan dokumentasi perkreditan yang lebih baik.

c. Untuk mengajukan efesiensi di dalam pengelolaan dan tata laksana usaha di bidang perkreditandan mendorong tercapainya rencana yang telanh ditetapkan.

d. Untuk menilai tingkat kepatuhan terhadap aturan yang telah ditetapkan dan penggarisan dalam manual perkreditan dalam pencapaian sasaran.

\section{Teknik Pengawasan Kredit}

Berikut ini teknik-teknik pengawasan kredit: 
a. Control by exception yaitu hal yang bersifat exception dapat diketahui dengan kekuatan, kelemahan, kesempatan, dan ancaman (analisa SWOT), sehingga dengan demikian sasaran dan intensitas pengawasan difokuskan pada hal-hal yang lemah (faktor-faktor intern) dan hal-hal yang menjadi ancaman/membahayakan (faktor ekstern).

b. Pengawasan fisik yaitu pengawasan yang langsung dilakukan ketempat usaha nasabah terhadap aktivitas usaha yang telah dilakukan dan atas hal-hal yang telah dilakukan dan atas hal-hal yang telah dilaporkan. Secara umum sasaran pengawasan fisik yaitu :

1. Personalia dan organisasi

Personalia dan organisasi dalam perusahaan turut menentukan kemajuan bank, oleh karena itu petugas yang melaksanakan On The Spot wajib menyelidikinya secara mendalam apakah kedua masalah ini telah memadai dengan aktivitas.

2. Administrasi dan keuangan perusahaan yaitu penyelenggaraan administrasi dan keuangan bank dapat memberikan gambaran tentang bagaiman aktivitas bank itu dijalankan.

3. Alat-alat produksi, aktivitas produk dan situasi lingkungan. Penelitian terhadap alat-alat produksi dan aktivitas produksi dapat dititik beratkan kepada beberapa hal yaitu lokasi usaha yang strategis, keadaan dan jumlah produksi.

4. Stock barang dagang yaitu bahan baku dan bahan setengah jadi diadakan penelitian dan pengecekan atas laporan yang disampaikan oleh nasabah terhadap keadaan stock.

c. Monitoring Perkreditan Yaitu :

BPR harus mengumpulkan data-data dan informasi baik informasi ekstern maupun informasi intern yang dikiombinasikan, untuk selanjutnyan diambil langkah-langkah pengamanan secara dini bila terhadap hal atau masalah yang mengarah timbulnya kerugian bank.

\section{Proses Dan Pengawasan Kredit}

Kegiatan pengawasan kredit mencakup unsur-unsur yang berupa langkah yaitu menetapkan kriteria pengawasan, sebelum melakukan pengawasan terhadap kredit bank harus terlebih dahulu menetapkan kriteria pengawasan. Kemudian menetapkan standar pengawasan, berdasarkan kriteria-kriteria pengawasan sebagaiman telah ditetapkan dapat dibuat standar pengawasan yang digunakan sebagai norma untuk menilai hasil-hasil pelaksanaan kegiatan debitur. Setelah itu melakukan proses penilaian untuk mengetahui proses pengawasan bank juga melakukan proses penilaian. Tindakan ini dilakukan secara umum dan khusus untuk mrmbandingkan kinerja, norma dan tujuan pemberian kredit.

Sedangkan pengawasan merupakan fungsi manajemen yang mencapai urutan paling akhir dalam tujuan manajemen. Pengawasan membantu penilaian apakah perencanaan, pengorganisasian, dan pelaksanaan suatu program telah dilaksanakan dengan efektif atau tidak.

Bagi perkreditan bank. Indikasi-indikasi penyimpangan dapat dideteksi melalui beberapa jenis monitoring. Jenis monitoring yang lebih efisien banyak tergantung pada penggunaan tenaga, waktu, biaya, dan risiko yang dihadapi sebab bank akan selalu mempertimbangkan hal tersebut. Indikasi-indikasi tersebut merupakan penyimpanganpenyimpangan atas terms of lending, dimana intinya adalah ketentuan otoritas moneter, ketentuan bank, prasyarat/syarat, dan hasil negosiasi antara bank dan nasabah.

1. Monitoring adalah untuk mengetahui secara dini penyimpangan yang terjadi dari kegiatan perkreditan (deviasi)sehingga bank dapat mengambil langkah-langkah secepat mungkin untuk perbaikannya. Namun, bank juga harus memilih jenis 
monitoring yang akan dipergunakan karena menyangkut masalah biaya dan efesiensi kredit itu sendiri. Adapun Monitoring ini diklasifikasikan dalam tiga jenis, yaitu :

On desk monitoring adalah pemantauan kredit secara administrastif, yakni melalui instrument-instrumen administrasi, seperti laporan-laporan, financial statement (neraca, 4R, sumber dan penggunaan dana), kelengkapan dokumen, informasi pihak ketiga. Dan data-data admnistrasi yang di monitor oleh bank adalah kegiatan nasabah dan bank sendiri, seperti yang dibawah ini.

Yaitu : proses pengawasan kredit adalah dari kredit yang diberikan, dilakukan pemeriksaan, apakah terjadi penyimpangan dari perjanjian antara pihak debitur dengan bank. Pada tahap ini, penyimpangan-penyimpangan tersebut diidentifikasikan dan dicari tahu apa yang menjadi penyebab terjadinya penyimpangan tersebut. Penyebab penyimpangan ini bisa dari pihak bank maupun dari pihak debitur. Penyebab dari pihak bank misalnya struktur organisasi yang lemah dari pihak bank, kurang akurat dalam melakukan penelitian sebelum memberikan kredit, dan sebagainya. Dan dari pihak debitur biasanya penyebabnya adalah menurunnya kondisi keuangan perusahaan.

On site monitoring yaitu pemantauan kredit langsung ketempat usaha nasabah.

Tujuan On Site Monotoring :

1. Meneliti kebenaran data atau keterangan yang disampaikan nasabah.

2. Meneliti secara langsung usaha nasabah.

3. Secara psikologis mengingatkan nasabah, bahwa bank menaruh perhatian atas usaha nasabah.

4. Mendidik nasabah untuk menyampaikan laporan sesuai kenyat.

\section{Aspek-Aspek Pengawasan Kredit Yaitu :}

Adanya administrasi kredit yang memadai dan mengadakan cara-cara mutakhir, seperti penggunaan computer on line system dan keharusan bagi nasabah kredit untuk menyampaikan laporan secara berkala atas jenisjenis laporan yang telah disepakati dan dituangkan dalam perjanjian kredit seperti :

a. Laporan produksi.

b. Laporan penjualan.

c. Laporan utang dan piutang perusahaan

d. Laporan keuangan (neraca, perhitungan laba rugi, dan lai-lain).

e. Laporan tenaga kerja.

f. Laporan asuransi aktiva tetap.

g. Laporan perubahan izin yang diterima dari instansi terkait.

Keharusan yang wira kredit (account officer) melakukan kunjungan (visit) keperusahaan atau proyek yang dibiayai bank, baik selama berlangsungnya pembangunan proyek maupun stelah proyek tersebut berjalan sebagai suatu usaha bisnis dan adanya konsultasi yang terstruktur antara pihak bank dengan debitur, terutama jika debitur memulai mengalami kesulitan dalam bisnisnya atau telah menunjukan tanda-tanda terjadinya kemacetan. Kesulitan tersebut mungkin terjadi pada berbagai masalah, seperti masalah produksi, pemasaran, tenaga kerja, keuangan, perpajakan, dan sebaginya.Konsultasi yang dilakukan secara dini pada umumnya dapat mengurangi atau menekan kemungkinan terjadinya kegagalan proyek atau kredit macet serta adanya suatu "system peringatan" (warning system) pada admistrasi bank atau umumnya dikelola oleh wira kredit mengenai nasabah yang bersangkutan peringatan dini tersebut dapat memperlihatkan kepada wirakredit berbagai informasi tentang nasabah kredit yang berkaitan dengan kepatuhan kepada ketentuan yang telah dibuat dalam perjanjian kredit misalnya: 
a. Pengasuransian berbagai aktiva tetap yang dimiliki nasabah, terutama aktiva tetayang dijadikan agunan ( jaminan kredit ) yang diserahkan kepada bank.

b. Besarnya nilai agunan yang masih ada dibandingkan dengan nilai sisa pinjaman (outstanding atau dari debit kredit),

c. Posisi nasabah berdasarkan kolektibilitas kreditnya pada setiap waktu, apakah nasabah masih tergolong kredit lancer ataukah sudah menjadi kredit kurang lancer, kredit diraguakan, ataukah ( bahkan ) kredit macet. Posisi nasabah ini erat kaitannyadengan sistem pelapran ke Bank Indonesia dan sangat menentukan dalam penilaian terhadap tingkat kesehatan bank yang bersangkutan.

\section{ANALISA DAN PEMBAHASAN}

\section{Proses Pemberian Kredit PT. BPR Ophir Pasaman Barat}

Proses pemberian kredit membutuhkan berbagai pertimbangan agar terhindar dari kemungkinan terjadinya hal-hal yang dapat merugikan. Selain dipengaruhi oleh ketentuanketentuan dari Bank Indonesia, kebijakan yang diberikan dan ditetapkan oleh bank juga berpengaruh pada pertimbangan serta analisis dalam pemberian kredit.

Bank dalam menerapkan kebijakan pemberian kredit sampai dengan pengawasan setelah kredit diberikan kepada nasabah merupakan hal penting bagi usaha perbankan. Tujuan utama pengawasan tersebut adalah untuk menjaga, mengamankan dan mengantisipasi terjadinya kredit bermasalah.

Proses pemberian kredit pada PT. BPR Ophir Pasaman Barat dapat di gambarkan sebagai berikut :

\section{Gambar}

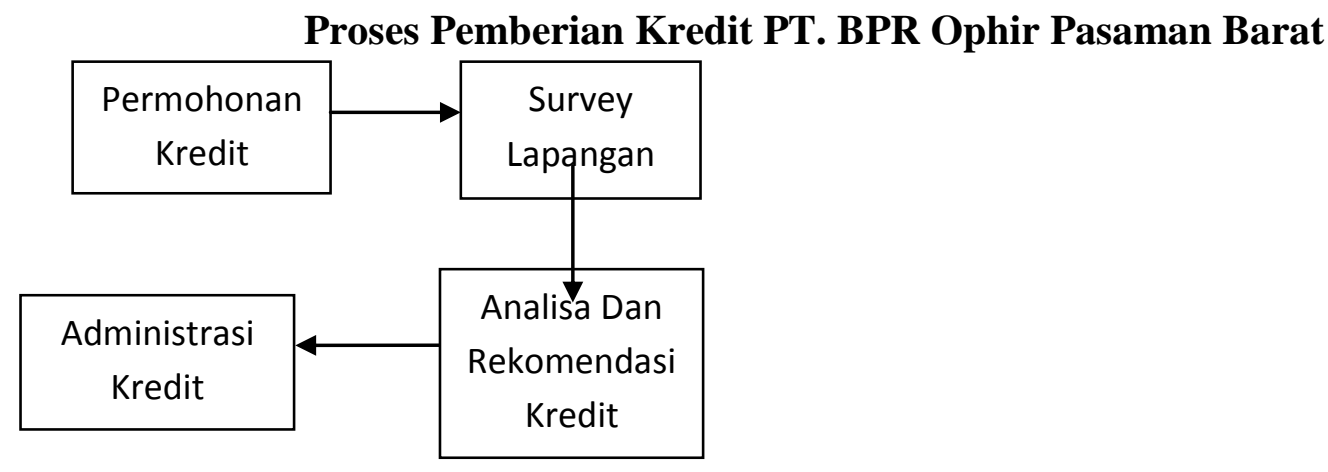

Sumber : PT. BPR Ophir Pasaman Barat

Adapu prosedur pemberian kredit pada PT. Bank Perkreditan Rakyat Ophir Pasaman

Barat adalah sebagai berikut :

a. Permohonan Kredit

Pemohon kredit menyampaikan maksud untuk permohonan kredit dan kepadanya dijelaskan ketentuan dan syarat-syarat yang berlaku dalam pemberian kredit dan jika yang bersangkutan berkeinginan, kepadanya diminta untuk:

1. Mengisi formulir permohonan kredit yang disediakan oleh bank.

2. Penyerahan dokumen lain yang berupa :

a. Foto copy kartu identitas berupa KTP suami dan istri calon debitur yang masih belaku.

b. Foto copy kartu keluarga.

c. Foto copy BPKB dan STNK kendaraan yang akan digunakan.

d. Pas photo $4 \times 6$ ( suami dan istri).

e. Foto copy jaminan dan lunas PBB terbaru.

3. Formulir pendaftaran yang telah dilengkapi disimpan di bank. 


\section{a. Survey lapangan}

Setiap permohonan kredit yang masuk akan diproses oleh pihak bank, setelah itu proses terhadap permohonan ini dimulai dengan mengadakan survey lapangan terhadap si pemohon kredit dan aktu pelaksanaan survey lapangan ditentukan oleh pihak bank.

b. Analisa dan rekomendasi kredit

Setiap permohonan kredit yang sudah di survey lapangan akan dianlisa oleh Account Officer (AO) kemudian analisa kredit disertai dengan rekomendasi kredit yang sudah dibuat Account Officer (AO) diajukan kepada Direksi dan kemudian Direksi akan mengadakan rapat komite bersama semua Account Officer (AO) atau bagian yang bersangkutan dengan pemberian kredit untuk mempertimbangkan layak atau tidak nasabah tersebut beri fasilitas kredit.

c. Administrasi kredit

Rekomendasi kredit yang sudah disetujui oleh Direksi akan diproses oleh petugas administrasi kredit untuk direalisasikan setelah itu petugas administrasi kredit akan mempersiapkan dokumen untuk keperluan realisasi kredit yaitu :

Seperti perjanjian kredit antara debitur dangan pihak bank, surat kuasa dari debitur kepada pihak bank untuk pengikatan jaminan, bukti pembayaran yang terdiri dari :

1. Bukti pindah buku realisasi kredit.

2. Pembayaran provisi, administrasi, asuransi kredit.

3. Kartu pembayaran angsuran kredit dan mengadministarikan secara baik setiap dokumen kredit yang sudah direalisasikan.

\section{Pengawasan Kredit PT. BPR Ophir Pasaman Barat}

Menurut Firdaus dan Ariyanti (2009:133) pengawasan merupakan suatu upaya meminimalisir kredit-kredit yang kurang lancar, diragukan atau macet. Pengawasan kredit yang dilakukan bank tidak hanya saat kredit tersebut diberikan kepada debitur saja, tetapi dimulai dari sebelum kredit tersebut diberikan sampai dengan kredit tersebut dikembalikan oleh debitur. Dalam tahapan pengawasan kredit pada umumnya dimulai dari pencairan kredit dan sampai pelunasan suatu kredit itu berakhir.

Pelaksanaan pengawasan kredit sangat perlu diterapkan secara berkesinambungan seiring dengan adanya resiko tunggakan kredit yang semakin meningkat. Pihak bank perlu secara aktif dalam melakukan peninjauan setiap usaha nasabah. Dengan demikian bank akan mengetahui nasabah yang kemungkinan akan mengalami penunggakan kredit sehingga pihak bank dapat mengantisipasi sejak awal.

Adapun proses pengawasan kredit yang dilakukan oleh PT.Bank Perkreditan Rakyat Ophir yaitu sebagai berikut :

a. Sebelum realisasi atau pencairan Kredit.

b. Melihat kebenaran data-data dan kelengkapan berkas kredit.

c. Pemantauan usaha nasabah dan melihat laporan keuangannya.

d. Penilaian terhadap prinsip-prinsip pemberian kredit, yaitu prinsip 5C dan 7P sehingga dapat menilai apakah calon debitur layak untuk diberi fasilitas kredit.

e. Penilaian terhadaap agunan atau jaminan kredit yang mencakup hal-hal sebagai berikut :

1. Bukti pemilikan jaminan atau agunan kredti.

2. Kondisi agunan (sehat atau tidak sehat) hal-hal yang akan merugikan bank, serta melakukan cek fisik terhadap agunan yang diberikan dengan tujuan pengantisipasian kerugian. 
3. Perkiraan nilai jual kembali, dengan tujuan untuk menhatasi apabila nantinya terjadi kredit macet maka terhadap agunan dapat menutupi hutang nasabah.

4. Pengikatan agunan atau jaminan dengan surat kuasa jual dan pengikatan lainnya dengan tujuan untuk mengatasi apabila nantinya debitur tidak membayar hutangnya maka dapat ditempuh dengan jalur pengadilan.

Sesudah realisasi atau pencairan kredit : Pengawasan kredit yang dilakukan PT.Bank Perkreditan Rakyat Ophir Pasaman Barat adalah sistem pengawasan kredit langsung yaitu :

a. Pemantauan terhadap ketepatan nasabah dalam membayar angsuran kredit.

b. Pemantauan terhadap ketepatan penggunaan kredit.

c. Pemantauan terhadap usaha nasabah yang telah mendapatkan fasilitas kredit, dan yang dinilai adalah apakah sudah ada peningkatan jumlah penjualan serta penambahan barang modal.

Setelah dilakukan pemeriksaan apakah terjadi penyimpangan dari perjanjian antara pihak debitur dengan bank pada tahap ini penyimpangan-penyimpangan tersebut diidentifikasikan dan dicari tahu apa yang menjadi penyebabnya terjadinya penyimpangan tersebut. Penyebab penyimpangan ini bisa dari pihak bank maupun dari pihak debitur, penyebab dari pihak bank misalnya struktur organisasi yang lemah, kurang akurat dalam melakukan penelitian sebelum memberikan kredit tersebut dan pihak debitur biasanya penyebabnya adalah menurunnya kondisi keuangan perusahaan.

Setelah dilakukan analisa terhadap penyebab penyimpangan tersebut, maka disusunlah suatu program untuk memperbaikinya. Dan dari pelaksanaan program itu nantinya akan dibandingkan dengan suatu standar yang baku dalam menentukan korektibilitas kredit, dalam tahap ini kredit akan di kelompokkan dalam kelompok lancar, dalam perhatian khusus kurang lancar, diragukan, dan macet.

Jika seandainya ada kredit yang mengalami masalah/terlambat membayar dan atau kredit macet maka piahak bank akan memberikan beberapa tahap untuk penyelesaian kredit yaitu sebagai berikut :

1. Memberikan SP 1 (surt peringatan) kepada nasabah yang terlambat membayar angsuran atau menunggak 1 bulan.

2. Memberikan SP 2 (surat peringatan) kepada nasabah yang terlambat membayar angsuran atau menunggak 2 bulan.

3. Memeberikan SP 3 (surat peringatan) kepada nasabah yang terlambat membayar angsuran atau menunggak 3 bulan.

4. Apabila upaya pembinaan terhadap kredit bermasalah sudah tidak dapat dilakukan lagi, dan sudah terjadi kredit macet maka akan dilakukan penyitaan terhadap agunan atau jaminan yang diberikan oleh nasabah.

5. Barang agunan yang sudah disita akan dibuat dalam berita acara dan kepada nasabah akan diberi tenggang waktu untuk membayar kewajibannya, apabila dalam waktu yang tentukan nasabah belum juga membayar kewajibannya maka akan dilakukan pelelangan agunan atau melalui urusan pengadilan.

Perkembangan Jumlah Kredit PT. Bank Perkreditan Rakyat Ophir Pasaman Barat.

Fungsi pokok sebuah bank yaitu menyediakan mekanisme dan alat untuk pembayaran efisien, juga menciptakan uang dan menawarkan jasa keuangan lainnya yang kemudiaan dialokasikan kedalam bentuk penggunaan dana kepada masyarakat suatu bentuk penyaluran tersebut adalah dengan melakukan pemberian kredit dan pihak bank harus melakukan fungsi pengawasan dengan baik. 
Adapun perkembangan jumlah kredit yang disalurkan oleh PT. Bank Perkreditan Rakyat Ophir Pasaman Barat setiap tahunnya, baik itu kredit umum pengusaha kecil, kredit khusus petani ophir, kredit PNS dan PENSIUN dapat dilihat pada tabel 1 dibawah ini :

Tabel 1

Perkembangan Jumlah Kredit PT. BPR Ophir Pasaman Barat

\begin{tabular}{|l|l|l|}
\hline \multicolumn{1}{|c|}{ Tahun } & \multicolumn{1}{|c|}{ Total Kredit } & Pertumbuhan \\
\hline 2011 & Rp. 27.313.606.000 & - \\
\hline 2012 & Rp. 32.779.748.000 & $3,28 \%$ \\
\hline 2013 & Rp. 33.714.988.000 & $3,37 \%$ \\
\hline 2014 & Rp. 31.715.365.000 & $3,17 \%$ \\
\hline 2015 & Rp. 34.314.899.000 & $3,43 \%$ \\
\hline
\end{tabular}

Sumber : PT. Bank Perkreditan Rakyat OphirPasaman Barat

Dari tabel 3.2 diatas dapat dilihat perkembangan jumlah kredit yang disalurkan oleh PT. Bank Perkreditan Rakyat Ophir Pasaman Barat mengalami peningkatan yang cukup berarti, sebab terlihat dari kenaikan jumlah kredit yang disalurkan meningkat pada tahun 2012 dengan jumlah Rp. 32.779.748.000 dengan pertumbuhan sebesar 3,28\%. Pertumbuhan kredit yang paling kecil terjadi pada tahun sebelumnya yaitu tahun 2011 dengan berkurangnya jumlah kredit sebesar Rp. 27.313.606.000, setelah itu pada tahun 2013 jumlah kredit yang disalurkan mengalami peningkatan kembali dengan pertumbuhan 3,37 \% dengan peningkatan sebesar Rp. 33.714.988.000 dan pada tahun 2014 kredit mengalami penurunan sebesar 3,17 \% dengan jumlah sebesar Rp. 31.715.365.000 dan pada tahun 2015 jumlah kredit yang disalurkan mengalami peningkatan yang sangat baik dari pada jumlah kredit yang sebelumnya yaitu mengalami pertumbuhan sebesar 3,43 \% dengan jumlah kredit sebesar Rp. 34.314.899.000. Dilihat secara umum pertumbuhan kredit terbesar terjadi pada tahun 2015 yaitu sebesar 3,43\% dengan jumlah kredit sebesar Rp.34.314.899.000.

\section{PENUTUP}

\section{Kesimpulan}

Berdasarkan dari hasil pemahaman teori dan pembahasan tentang Pengawasan Kredit oleh PT. BPR Ophir Pasaman Barat atau pada bab-bab sebelumnya, penulis dapat menarik beberapa kesimpulan sebagai berikut :

a. KBPR Ophir berubah menjadi PT. BPR Ophir Pasaman Barat dan melakukan RUPS pertama pada 21 Januari 2015 dengan modal dasar Rp. 10.000.000.000 dan modal disetorkan Rp. 3.574.760.000.

b. Aktivitas utama PT. Bank Perkredita Rakyat Ophir Pasaman Barat ini adalah menyalurkan dana ke masyarakat di serahkan dalam bentuk kredit. Jenis - jenis kredit yang disalurkan adalah Kredit Khusu Petani Ophir (KKPO), Kredit Umum Pengusaha Kecil (KUPK), serta Kredi PNS dan PENSIUN.

c. Pengawasan Kredit yang dilakukan PT. Bank Perkreditan Rakyat Ophir Pasaman Barat dimulai dari tahapan permohonan sampai kredit tersebut lunas sudah berjalan dengan baik.

d. Penulis mengambil kesimpulan bahwa Pengawasan Kredit mempunyai peranan penting khususnya bagi pemberian kredit untuk memperkecil resiko dari kredit macet, pengawasan juga bisa mengantisipasi adanya kemungkinan-kemungkinan terjadinya resiko dan pengawasan yang dilakukan dalam pemberian kredit dapat mengurangi kerugian pada bank yang diakibatkan oleh adanya kredit macet. 


\section{Saran}

1. Untuk mengantisipasi terjadinya resiko, agar pengaruh negatif terhadap perkreditan bank dapat diminimalkan, karena tidak ada suatu kredit yang macet secara tiba-tiba dalam tahap pemberian kreditan melainkan terdapat indikasi-indikasi yang bisa di deteksi melalui proses pengawasan kredit.

2. Dengan adanya Pengawasan Kredit ini, maka pihak PT. Bank Perkreditan Rakyat Ophir dapat lebih mudah untuk menjaga dan mengamankan kredit.

3. Agar penerapan pengawasan kredit dapat mencapai sasarannya, yaitu pengusaha kecil dan menengah, hendaknya PT. Bank Perkreditan Rakyat Pasaman Barat menjalankan prinsip kehati - hatian dan mematuhi kebijaksanaan yang ada.

4. Sebelum memberikan kredit para karyawan memberikan arahan terlebih dahulu mengenai kredit yang akan diberikan pada calon debitur sampai mereka mengerti sehingga tidak terjadi kredit bermasalah.

\section{DAFTAR PUSTAKA}

Amelia, L., \& Marlius, D. (2018). Pengendalian Kredit Dalam Upaya Menciptakan Bank Yang Sehat Pada PT. Bank Pembangunan Daerah Sumatera Barat Cabang Utama Padang. https://doi.org/10.31227/osf.io/kpc64

Alanshari, F., \& Marlius, D. (2018). Prosedur Pemberian Kredit KPR Pada PT. Bank Tabungan Negara (Persero) TBK Cabang Pembantu Bukittinggi. https://doi.org/10.31227/osf.io/rsfhc

Astiko. Manajemen Perkreditan. Yogyakarta: Andi Offset, 1996.

Darmawanto, \& Fernos, J. (2019). Prosedur Pemberian Kredit Pada Bank Nagari Cabang Sijunjung. https://doi.org/10.31227/osf.io/psqfy

Baiya, \& Fernos, J. (2019). Analisis Faktor-Faktor Penyebab Kredit Macet Pada Bank Nagari Cabang Siteba. https://doi.org/10.31227/osf.io/4xuks

Firdaus, R. \& Ariyanti, M (2009), Manajemen Perkreditan Bank Umum, Bandung: Alfabeta.

Firmansyah, A., \& Fernos, J. (2019). Analisis Kredit Bermasalah Dilihat Dari Standar Non Performing Loan (NPL) Pada PT. Bank Perkreditan Rakyat (BPR) Prima Mulia Anugrah Cabang Padang. https://doi.org/10.31227/osf.io/gcj94

Handoko, T Hani. 2001. Manajemen Personalia Dan Sumberdaya Manusia,Edisi Kedua. BPFE, Yogyakarta.

Ikbal, M., \& Marlius, D. (2017). Pengaruh Jumlah Taksiran Dan Uang Pinjaman Terhadap Laba Bersih Pada PT. Pegadaian (UPC) Gurun Laweh. https://doi.org/10.31227/osf.io/uch4a

Kasmir. (2002). tentang “dasar-dasar perbankan”, PT.Raja Grafindo Persada, Jakarta.

Kasmir, 2003. Manajemen Perbankan, Edisi Revisi, PT. Raja Grafindo Persada, Jakarta. 
Kasmir. S.E., M.M 2008. Bank dan Lembaga Keuangan Lainnya. Jakarta: PT. Raja Grafindo Persada.

Pratama, D., \& Fernos, J. (2019). Prosedur Pelaksanaan Kredit Usaha Rakyat (KUR) Pada PT. Bank Nagari Cabang Padang. https://doi.org/10.31227/osf.io/ag68j

Undang-undang No.10 tahun 1998 tenteng perubahan atas undang-undang No.7 tahun 1992 tentang perbankan. 